Nuntius Antiquus, Belo Horizonte, v. 13, n. 2, p. 263-283, 2017

\title{
The Paradox of Literary Emotion: An Ancient Greek Perspective and Some Modern Implications
}

\author{
O paradoxo da emoção literária: uma perspectiva \\ grega antiga e algumas implicações modernas
}

\author{
Dana LaCourse Munteanu \\ Classics Department \\ Ohio State University, Newark, Ohio / USA \\ munteanu.3@osu.edu
}

\begin{abstract}
Fifth-century BCE Greek writers (e.g., Isocrates, Pseudo-Andocides) complain that the Athenians might have been more deeply moved by tragedies than by horrific contemporary events. My essay suggests that literary narratives could indeed produce this effect on us through several features. (1) The feeling of personal safety, threatened sometimes by our showing compassion to others (e.g. Euripides' plays, Thucydides; modern refugee debates) remains intact when we engage in fiction. (2) The proximity to literary characters becomes enhanced by literary narratives (pro ommaton, focalization), in contrast to impersonal journalistic reports. (3) The universality ascribed to a literary piece (Aristotle's Poetics) could contribute to our emotional immersion into the world of fiction to the detriment of the surrounding reality. While each section starts from ancient Greek authors, the essay will underline some similarities between the classical and the modern ways of engaging with literary narratives.
\end{abstract}

Keywords: Emotional paradox; universality of literature; focalization; historical narrative; journalism versus literary narrative.

Resumo: Escritores gregos do século V a.C. (por exemplo: Isócrates, PseudoAndocides) reclamam de os atenienses poderem ter sido mais afetados pelas tragédias do que pelos terríveis acontecimentos contemporâneos a eles. Meu ensaio sugere que narrativas literárias poderiam de fato produzir esse efeito em nós por meio de vários atributos. São eles: (1) Nosso sentimento de segurança pessoal, ameaçado algumas vezes quando mostramos compaixão pelos outros (por exemplo, nas peças de Eurípides, em Tucídides; nos debates atuais sobre refugiados), permanece intacto 
quando engajamos em ficção. (2) A proximidade com personagens literários torna-se intensificada pelas narrativas literárias (pro ommaton, focalização), em contraste com relatos jornalísticos impessoais. (3) A universalidade que nós atribuímos a uma peça literária (Poética de Aristóteles) poderia contribuir para nossa imersão emocional em um mundo de ficção em detrimento da realidade circundante. Enquanto cada sessão começa fundando-se em autores antigos, o ensaio irá enfatizar algumas similaridades entre os modos clássico e moderno de engajamento com narrativas literárias.

Palavras-chave: paradoxo emocional; universalidade da literatura; focalização; narrativa histórica; jornalismo versus narrativa literária.

\section{The paradox of our emotional involvement in literature - an introduction}

Is it possible that we care more about fictional characters, who are not real, than about our fellow human beings, who truly exist and suffer? Paradoxically, can fiction stir our emotions more than reality? The starting point of my discussion will be fifth and fourth-century Greek philosophers and orators, to which I shall add some modern parallels. As several classicists have convincingly shown, emotion should be understood in its cultural context and unveiled with patience by historians and philologists. ${ }^{1}$ Notwithstanding the cultural nuances, the concept of emotion carries certain universal and cross-cultural characteristics. ${ }^{2}$ What I propose next is not a nuanced analysis of the ancient Greek emotional responses to literature, but, rather, an examination of the ancient fascination with the intensity of the emotional responses to drama, contrasted with the relative indifference to historical atrocities. This attitude sometimes puzzled ancient thinkers and, to an extent, it has continued to puzzle us. Obviously, our modern responses to literary

\footnotetext{
${ }^{1}$ Most prominently, Konstan (2001) has shown the differences between the ancient concept of pity and its later Christian transformation; Konstan (2006) has focused on the specificity of the classical Greek emotions. Overall useful discussions of the cultural differences between the ancient and the modern emotions could be found, for example, in Chaniotis (2012) and Konstan (2015); Cairns and Nelis (2017, p. 1-18).

${ }^{2}$ Illuminating on this topic is Cairns' (2008) analysis.
} 
narratives and, respectively, to the news do not perfectly correspond to the ancient reactions: many types of current media (tv reportage, for example, providing an immediate visual account of events) have no equivalent in the past and thus no point of comparison. Without positing equivalence between the ancient and the modern experiences, I shall underline from a broad philosophical perspective certain similar tendencies in our engaging with fiction, while ignoring reality.

The orator Isocrates (436-338 BCE), in his Panegyricus (4.166167), lists the challenges of his generation in the years following the Peloponnesian War, around 380 BCE. $^{3}$ The Persian king subjugated many unwilling people and mistreated numerous allies of Athens: some of these were killed, others migrated with their wives and children, yet others lacked their daily needs and, consequently, were forced to fight as mercenaries for their former enemies. Nonetheless, this state of affairs left the Athenians cold:

Against these [abuses] nobody has ever felt indignant, but people find worth shedding tears over misfortunes put together (sygkeimeinais) by poets, while paying no attention to many true (alethina) and terrible sufferings which have occurred because of war; far from feeling pity for these, people take more delight in the misfortunes of others than in their own blessings (Panegyricus, 168). ${ }^{4}$

Isocrates compares here stories invented by poets to real misfortunes of people oppressed by the Persians, complaining that the former bring Athenians to tears whereas the latter, true (alêthina) afflictions, arouse no pity. ${ }^{5}$ Is Isocrates' own frustration sincere in this case? We may detect a hint of exaggeration, as the orator rebukes his audiences not only for

\footnotetext{
${ }^{3}$ On the historical background of these sections of Panegyricus, proposing a pan-Hellenic expedition against the Persian king, see Usher's commentary (1990, p. 195-197).

${ }^{4}$ Translations from Greek are mine, unless specified otherwise.

${ }^{5}$ In an earlier article (2009, p. 128-131), I have discussed this passage and a similar one from pseudo-Andocides (Alcibiades 4.23.201-206), in which the orator critiques the Athenian passivity toward Alcibiades' abusive behavior, which would be considered intolerable if it had been displayed in tragedies.
} 
being indifferent to the plight of the allies but also for feeling a kind of schadenfreude, pleasure at another's troubles. ${ }^{6}$ Yet, can there be any truth in Isocrates' observation? It seems counter-intuitive that people would rather respond with pity when they contemplate fictional ills rather than when they see real ones. However, I propose, this is not only possible, but also a frequent outcome of our interactions with the real and fictional worlds. I examine three reasons which make this paradox likely, arguing that it is possible to care more intensely for literary narratives than for narratives related to real events on account of the (1) safety, (2) proximity, and (3) universality offered by fiction. Indeed, we may care more for fictional characters because of our safety as observers, our imaginative proximity to the (fictional) sufferers, and, possibly, through our attaching a broad and deep meaning to the narrative. My analysis will concentrate first on ancient Greek texts, but it will also signal some similarities between the classical thought and modern views.

\section{Safety}

Feeling compassion can prompt us to try to alleviate suffering. However, helping others may come at a cost to ourselves: diminished resources, time, and, sometimes, personal danger. In this section, I examine several ancient Greek texts that emphasize precisely the perils of acting on account of compassion. The anxiety regarding aiding others vanishes, however, when we deal with fictional characters: first, they cannot hurt us and, second, we cannot truly help them. This is not because

\footnotetext{
${ }^{6}$ Through the lens neuroscience, oddly enough, this reaction mentioned by Isocrates could have been possible. Sapolky (2017, p. 528-534), describes experiments showing that when people feel empathy, the anterior cingular cortex activates, which broadly interprets the meaning of pain (our own pain and other people's). This part of becomes easily activated when observing people like us in pain. However, when asked to empathize with people we dislike who are in pain, the anterior cingular cortex does not activate; instead the mesolimbic dopamine reward system does, which is linked to feeling excitement. In this light, therefore, it possible to speculate that some Athenians disliked their alies to such an extent that they may have felt pleased at hearing their misfortunes.
} 
we do not feel the impulse to intervene, in my opinion, but because we know that we cannot do so - and, therefore, we can let our empathy grow from a position of safety.

Late fifth-century Euripidean tragedies and certain speeches in Thucydides histories seem to capture an increased tension between pity for another and self- preservation. In several plays of Euripides, characters either afflicted by real misfortune or merely pretending to suffer, appeal to the benevolence of others only to betray them later. ${ }^{7}$ Problems related to showing mercy to suppliants in Euripides as well as in Thucydides, I suggest, may be a reflection of the ethical difficulties that challenged the Athenians before, during, and shortly after the Peloponnesian War. ${ }^{8}$ The examples selected will show close linguistic correspondences between Euripidean plays questioning the legitimacy of pity and the debates over the treatment of the allies of Athens in Thucydides.

Pity is an emotion based on the imagination or remembrance, on the abstract apprehension that we are all prone to suffering, according to Aristotle; however, when feeling pity, one should not fear directly that he or she will suffer as a result of trying to help another. ${ }^{9}$ Therefore, those people in distress must demonstrate their innocence and good will toward us in order to arouse pity. Several Euripidean tragedies, nevertheless, present disturbing scenarios in which some characters appear to be helpless, but hurt their benefactors, while others pretend to be in distress in order to ensnare their opponents. In the most shocking situations, the person who feels compassion anticipates that personal danger could occur from compassionate intervention and, therefore, vacillates between the impulse to help and the instinct of self-preservation. In Euripides'

\footnotetext{
${ }^{7}$ I have examined some of these traps of pity in Eurpidean drama, in passing, earlier (2012, p. 226-231), but did not connect the specific tragedies directly to historical accounts there.

${ }^{8}$ As Tzanetou (2012, p. 67-71), for example, has suggested, Euripides' Children of Heracles and Suppliant Women mirror features of the hegemonic ideology in Athens. I propose that late Euripidean plays might echo certain tensions between power and mercy in political interactions, which were relevant for the Athenian relationships with its allies and foes.
}

${ }^{9}$ On this, see my detailed discussion (2012, p. 70-103). 
Medea, for example, Creon, the king of Corinth, orders Medea's exile, deeply fearing her anger toward Jason and hatred of royal family (Med. 271-276). ${ }^{10}$ Medea insists that she could not be dangerous, arguing that she had been maligned (Med. 292-306), and asks Creon not to be terrified of her (Med. 307). The king notes that she speaks "soft words" (malthaka, 316), but he is filled with dread (orrôdia, 317) ${ }^{11}$ at the evil deed she might plan. Despite the king's unrelenting fear, Medea manages to obtain a kind concession from him: one more day in Corinth, for the sake of her children (Med. 344). She is successful when she reminds Creon that he is a parent too (Med. 344), so his own child could suffer a similar misfortune one day. ${ }^{12}$ Indeed, Creon allows Medea to stay one more day, aware that he might be "making a mistake" (examartanôn, Med. 350). Ironically, Creon's daughter will directly suffer and die as a consequence of his misguided pity. Although Medea is in truth suffering, she can still harm Creon; in his turn, Creon is aware of this and knows very well that he should not yield to pity, and yet he does, bringing destruction upon his own family.

In Euripides' Helen, the heroine never went to Troy but lived in Egypt, at the court of king Theoclymenus. Reunited with her husband, Menelaus, in the foreign land, Helen invents a plot to escape. She declares that Menelaus has perished during a shipwreck, and, therefore, she has to perform a funeral at sea for him, as required by a Greek custom. As a messenger recounts, after the ship departed from the shore, Menelaus and his people sailed away, managing to fool and defeat the Egyptian

\footnotetext{
${ }^{10}$ Johnson and Clapp (2005, p. 140) take the scene in the Medea as a reflection of social awareness that "the appeal for compassion also contained the potential for abuse; there was always the risk that a treacherous suppliant should arouse pity to perverse ends." For further political implications of the appeal to Creon, see also Luschnig (2001).

${ }^{11}$ This term has been linked to the reaction of coiling at seeing a snake; it suggests Creon's strong, instinctive reaction of dread at the sight of distraught Medea.

${ }^{12}$ Janko (2008) argues that Medea also manipulated the ancient (external) audiences and us, modern audiences, into feeling pity for her because of her misfortune but then made us regret our emotion when we observe her murderous actions at the end of the play.
} 
crew. Menelaus himself, acting as if he were a slave who escaped the shipwreck (that supposedly killed Menelaus), led the procession:

[Menelaus] spoke to them displaying a show of deceptive pity in the middle of the assembly (oikton es meson pherôn):

Oh, unfortunate, from what Achaean ship do you come after wrecking your boat?

But let us bury the son of Atreus who has perished and for whom the daughter of Tyndareus is giving a funeral in absence

They, shedding tears in a feigned way, embarked carrying sea-offerings for Menelaus. (Hel. 1542-1549)

"Bringing into public view" (es meson pherôn, Hel. 1542) is a formula used in the Athenian political life. ${ }^{13}$ What is the significance of the treacherous pity" (dolion oiktos, Hel. 1542) brought into the public space? On the one hand, the emotion of pity here is based on false premises, the false burial, metatheatrically resembling a tragic performance, in which actors only pretend to die. Furthermore, the Greek sailors, resembling a chorus who follow the lead actor, shed tears in a "feigned" (poietô), or "made up," way (Hel. 1547). ${ }^{14}$ On the other hand, pity produces disempowering effects because, under its spell, the Egyptian crew lose their ability to react to an attack planned against them. Like Creon, the Egyptians first did not want to let their guard down, feeling "suspicion" (hupopsia, Hel. 1549) that so many Greeks were mounting the ship, but they obeyed the orders of Theoclymenus, ${ }^{15}$ and allowed the feigned funeral to proceed to their own detriment.

\footnotetext{
${ }^{13}$ On this and alternative readings, see Burian (2007, p. 230), following Diggle on line 630; 286 on line 1542; Cf. LSJ, II b.

${ }^{14}$ Segal (1993, p. 65) provides a fascinating discussion of instances of weeping in Greek tragedies, which can be the sign of either authentic emotion or of feigned compassion (e.g., E. Hec. 953-955).

${ }^{15}$ As internal spectator, Theoclymenus himself seems convinced of the authenticity of Helen's mental anguish (Hel. 1192), even though there is no indication that he shares her grief; on the contrary, it serves his purpose that she has "lost" her husband and thus he could marry her.
} 
In my view, the tensions surrounding displays of pity in Euripides' tragedies, and especially the hesitations pertaining to acting on account of the emotion, can well relate to the ethical problems that challenged the Athenians during the Peloponnesian War and shortly afterwards. While in Herodotus appeals to pity do not occur consistently, in Thucydides such appeals register ten occurrences, with a concentration in book three (where eight out of ten references appear), in two cases in sets of opposed speeches (3.36-50 and, respectively, 52-68 the treatments of Mytilene and Plataea). ${ }^{16}$ One example that illustrates how historical narratives correspond to the moral dilemmas found in tragedies should suffice here. Let us focus on book three of Thucydides' Peloponnesian War, particularly on the Athenian debate over the treatment of the citizens of Mytilene, a city in Asia Minor that rebelled against Athens in 428 BCE. A first decision in $427 \mathrm{BCE}$ was that men be put to death, women and children be sold into slavery, but the Athenians changed their mind. Cleon, the Athenian politician, comments on this decision as follows:

I have often before been sure that democracy cannot rule, but never more certain than now, because of your change of mind regarding Mytilene. Fears of plots unknown to you in everyday relationships with each other (pros allelous) exist, and you feel the same with respect to your allies (symmachous), and yet never consider the mistakes that you may make (hamartete) listening to their appeals, or yielding to your pity (oiktoi); those are full of dangers to yourselves; you will not receive the gratitude (charin) of the allies for being soft (malachizesthai). (3.37.1-2)

In response, Diodotus proposed that only the guilty men be executed, but he did not encourage pity either (3.48). ${ }^{17}$ The Athenians followed Diodotus' less harsh proposal. Let us return for a moment, however, to the ideas and language of Cleon's speech. First, I would

\footnotetext{
${ }^{16}$ Lateiner (2005), especially p. 87-97.

${ }^{17}$ Fulkerson (2008) well emphasizes the similarities in the emotional appeals of the speeches of both Cleon and Diodotus, despite the differences between them. On the contrast and resemblance between the two speeches, see also Price (2001, p. 92-95).
} 
like to emphasize the hyperbolic beginning of the discourse: the entire democratic system may collapse because of one political decision. ${ }^{18}$ By exaggerating the consequences of one action, Cleon wants to shake his audience into reconsidering their mercy. Moreover, Cleon's reproof here is reminiscent both verbally and conceptually of Creon's address to Medea in Euripides' play. The Athenians "make a mistake" (hermatete) in Cleon's opinion, if they concede to any form of compassion for the defeated enemy. Likewise, Creon displayed an awareness of making a mistake (examartanon, Med. 350), when he allowed Medea another day. In both cases, the decision is not based on full compassion (the guilty Mytilenians were already punished and several others were going to be) and Medea was still going to be exiled. Nonetheless, even partial pity for the enemy brings danger to oneself. The words of Medea sounded "soft" (malthakoi), so that Creon listened to them in spite of being terrified of her plans. Similarly, the Athenians showing mercy are seen to become soft (malachizesthai). Most interestingly, perhaps, in Cleon's speech, as related by Thucydides, relationships between city states seem to resemble interpersonal interactions (the Athenians collectively form a body that can be harmed by compassion). In both the Euripidean drama and the Thucydidean passage, fear that an enemy, even a defeated enemy, might seek revenge if he is shown mercy should be a deterrent from the formation of compassion.

Thus far I have tried to show how ancient Greek tragedy and historiography reflected on the dangers of feeling compassion for another in the real world. We can understand how our reluctance to care for those in distress started early with concerns about our own self-preservation and well-being. Not that much has changed since fifth-century Athenian rhetoric. If we examine current articles about our own debates over helping Syrian and other middle-Eastern refugees, we can find similar points. Here is only one example, and please note the emphasis on making a "mistake." A title of an article in the National Review brings the same

\footnotetext{
${ }^{18}$ As Wohl (2002, p. 98-99) points out, Cleon loses the debate, but the danger hidden in the seductive power of rhetoric for the Athenian democracy remains a persistent motif in Thucydides' text.
} 
notion of hyperbolic collapse of a system that started Cleon's speech: "Europe is Making a Fatal Mistake" (September 15, 2015). The author, Dennis Prager, of Jewish descent, notes that by allowing so many refugees to come in "Europe will end up in a catastrophe for Europe and therefore for the West." He makes this observation admittedly with a heavy heart. Despite the true human tragedy, he concludes, compassion will lead to Muslim communities unable to integrate into Western societies and more economic trouble for the welcoming countries. ${ }^{19}$ A similar concern had surfaced in the ancient Greek texts: helping another could lead to the self-destruction, either on a small individual scale or on the larger scale of entire communities.

In this section, I have examined our reluctance to become emotionally involved in the lives of our fellow humans. By contrast, we can suppose that no such hesitations and fears impede our inclination to feel for fiction. If this supposition is correct, it follows that, free from worries and responsibilities, we may then feel more compassion for fictional beings than for real people in certain instances. This may be particularly true in cases in which the person who is our object of compassion may present a threat to ourselves. We may hesitate approaching someone with a festering wound, for fear of contagion, and yet, Sophocles' Philoctetes elicits our unwavering pity. Reading about the plight of the suppliants in Athenian tragedy moves us, but it appears much harder to reach a common decision as people to help contemporary refugees in our communities. Our position of safety as spectators or readers of fictional misfortunes can thus be counted as the first reason for which Isocrates might have been right in this respect. In the next two sections, I shall look more positively at what exactly compels us to care deeply for fictional others.

$19<$ http://www.nationalreview.com/article/424001/syrian-refugees-europe-mistake>, retrieved April 17, 2017. 


\section{Proximity}

In his Rhetoric, Aristotle insists that suffering should appear to be close at hand (eggys), in order to be pitiable (Rh.2.1386a29). He seems to imply both a spatial and temporal proximity, for, he adds, people do not feel pity for events that occurred thousands of years in the past or future. Orators, therefore, ought to bring suffering before the listener's eyes, by using their gestures, words and acting, thus bringing it closer to the minds of his audiences (Rh.2.1386a-1386b1). Presumably, the rhetoricians to which Aristotle addresses this piece of advice would deliver speeches about contemporary circumstances. Why, then, this concern that those events may appear distant and have to be acted out and brought closer? Presumably, accounts of other people's pain fail to move listeners, Aristotle intuits, unless they provoke their imagination with dramatic vividness. Indeed, this Aristotelian observation is confirmed by modern psychological studies. As Krznaric has noted in a recent book, "apart from spatial and social distance, a third form, temporal distance, also weakens the possibilities for empathy." ${ }^{20}$ The extraordinary implication in Aristotle's advice to the orators is that a dramatic mode of presentation should be adopted in place of ordinary speech, because it increases the impression of closeness to the sufferer necessary for arousing empathy. Ancient literary theory offers further ideas on how to bring the narrative "closer" to the listeners through terms such as enargeia and pro ommaton, which anticipate the modern notion of focalization. Enargeia, often translated as "vividness" refers in fact to a graphic quality of the narrative through which the reader is enabled to become a virtual witness, a spectator, and similarly, pro ommaton relates to the writer's talent to bring the narrated events in close proximity to his audience, as if they would just happen before their eyes. ${ }^{21}$

\footnotetext{
${ }^{20}$ Krznaric (2015, p. 44).

${ }^{21}$ Nünlist (2009, p. 193-194) well underscores this nuance of enargeia: graphic power of words that enthrall the audience. I have discussed (2012, p. 85-93) the importance that Aristotle assigns to pro ommaton for both good oratory and drama in the Rhetoric and the Poetics.
} 
Could we link Aristotle's recommendation regarding pity to Isocrates earlier statement that Athenians show more emotion when they attend dramatic performances than when they hear about the distress of their contemporaries? The narrative mode itself may have made a difference. Reports about the suffering of the allies could have sounded vague and unfocused, whereas Greek tragedies center precisely and intensely on the plight of a family. For example, in Euripides' Trojan Women, a play written toward the end of the fifth century (415 BCE), based on a legendary war, Hecuba laments the death of her grandson, Astyanax, who has been brought to her on a shield by Talthybius. Her indignation, pain, and despair are apparent in her address to the cruel victors who executed the boy:

Achaeans! All your strength is in your spears, not in the mind. What were you afraid of, that it made you kill this child so savagely?" ... (1158-1160). ${ }^{22}$

Furthermore, we come in close proximity with her dashed hopes and desires for her grandson, which personalize her loss more than the nameless victims in the news reports:

O darling child, how wretched was this death. You might have fallen fighting for your city, grown to man's age, and married, and with the king's power like a god's, and died happy, if there is any happiness here.

But no. You grew to where you could see and learn, my child, Yet your mind was not old enough to win advantage of fortune. How wickedly, poor boy, your father's walls, Apollo's handiwork, have crushed your pitiful head Tended and trimmed to ringlets by your mother's hand, And the face she kissed once, where the brightness now is blood Shining through the torn bones, too horrible to say more. (1167-1177).

Even though no photograph accompanies this tableau, Hecuba's account prompts us to imagine the scene in all its horrid details: the dead mangled body of a child hurled into the city walls, which should have protected

${ }^{22}$ All the translations from Trojan Women are from Lattimore (1958). 
him. Because the fictional account recreates a scene as if before the audiences' eyes, the Athenians may have felt more sadness for the fictional character, on hearing his grandmother's lament than they did for the unknown real children of the allies whose death they could not imagine.

But can we still be moved more deeply by fictional than by real misfortunes? News reportage in our times can sound quite dull, even when the events described are horrific. We supplement the words with photographs, but the two media often flash in front of our eyes for a few seconds, without a coherent story able to settle our impressions and to connect us to the people who have been part of the incidents. A recent report from Syria (13 December 2016), entitled "Civilians Killed as Battle from Aleppo Nears End," briefly describes the chaos in the streets, wounded people still trapped under buildings, and civilians summarily executed. It ends with statistics: "the government assault has been backed by heavy artillery and air strikes with at least 463 civilians, including 62 children, killed in Eastern Aleppo since Mid-November...Another 130 people, including 40 children, have been killed in the city's western districts by opposition rocket fire. ${ }^{23}$ Although most of us find the news upsetting, it is difficult to form an empathic bond with the victims who appear anonymous, depersonalized, and listed by number. ${ }^{24}$ Similarly, it is less likely that we feel grief on hearing such reports. A more visceral reaction to war atrocities can come from reading literary narratives, even when we are perfectly aware that those do not deal with real events. The technique coined in modern theory as "focalization" permits us to witness the experiences of fictional others from a position of proximity. ${ }^{25}$ Through this, two elements bolster our emotional involvement: the narrowing of our focus and a better understanding of another's perspective.

${ }^{23}<$ http://www.aljazeera.com/news/2016/12/civilians-killed-spot-battle-alepponears-161213133240891.html>, retrieved April 17, 2017.

${ }^{24}$ Butler (2009, p. 33-62), for example, observes that this depersonalization of the victims of war in the media occurs even more prominently when we deal with the "other": the foreign civilian casualties and the anonymous enemies, than when we deal with the loss of our own people in wars.

${ }^{25}$ Genette (1988) explains his earlier ideas on focalization and develops the concept. 
Psychological studies confirm that reporting large numbers of casualties without enough context numbs the compassion of the listeners ${ }^{26}$ and, conversely, identification of individual sufferers increases our desire to help. ${ }^{27}$ Successful literary narratives manage to transport us in the proximity of others, so that we can imagine seeing them and understand how it is like to be in their position. For example, a novel, such as such as Harriet Stowe's Uncle Tom's Cabin, published in 1852, galvanized the abolitionist movement in the States. ${ }^{28}$ This book could draw attention and bring the readers "closer" to the reality of slavery through a unified and compelling fictional narrative.

\section{Universality (Broader Relevance)}

Despite the illusion of proximity to fiction, our emotional involvement in the fictional death of Astyanax compared to our relative indifference to the death of many real children may appear at first paradoxical, irrationally unfair, and ultimately silly. Yet, it seems to me, it is not entirely so. Our sadness at the end of Euripides' Trojan Women comes not only from the artistry of the dramatist who managed centuries ago to put into words the anguish of an imaginary character, an old war captive about to bury her grandchild. We may have an intuition that this scene captures a dire situation that has frequently taken place in wartime and will continue to occur: in the aftermath of war the normal order of things can be reversed, so that the old bury the young. In that way,

\footnotetext{
${ }^{26}$ Slovic and Slovic (2004). Prinz (2011, p. 227-230), citing previous psychological studies lists the problems pertaining to empathy: the similarity bias and the local nature of empathy. The two are interconnected: we can feel only for people like us; outsiders can be perceived as similar to us but not in great numbers, so in Prinz' view empathy is not a solution to global problems.

${ }^{27}$ Dillard has described the phenomenon of compassion fatigue, as we realize that a massive group needs our help; as Slovic (2007), http://www.apa.org/science/about/ psa/2007/11/slovic.aspx, writes adding to Dillard's observations, "perhaps the blurring of individuals begins at two!" - and we can relate empathically only to individuals. ${ }^{28}$ On the influence of this novel on society, see Reynolds (2012).
} 
fiction can lead us back to reality. As Aristotle has put it in the Poetics (9.1451a36-1451b11):

The function of the poet is this not to narrate events that have happened, but things that may happen (hoia an genoito), according to probability (kata to eikos) and necessity (to anankaion). For the historian and the poet are not different with respect to whether they write in meter or without meter (the works of Herodotus could be put into meter, but they would be no less history in meter than they are without). The difference is that the former (historian) describes things that have happened, whereas the latter (poet) things that may happen. Therefore, poetry is a more philosophical and serious matter than history; poetry tends to speak of universals, history of particulars. A universal is the type of thing that a certain type of person may say or do, according to probability (kata to eikos) and necessity (to anankaion) - and this is what poetry aims at, even though it gives names (to characters). A particular is what Alcibiades did or suffered.

Aristotle gives recommendations here to the writer, to compose in accordance with the criterion of probability, to the point to which giving characters individuality and names becomes an accidental feature of the poetic creation. Consequently, the reader (or spectator) becomes transported through imagination into how it is like to be in a certain situation. Does this mean that someone experiences various scenarios and lives through literature? Certainly, and many have emphasized this aspect of the universality of literature. ${ }^{29}$ Yet, our recognition of universal features of an artistic work does not remain abstract. Universality and reality can become interlinked. As Aristotle urges the poet to encapsulate universality into his creation, through probability and necessity, so we, as respondents to literature recognize those features and may return to our immediate reality to reaffirm them. So, for example, even though Euripides' Trojan Women was written over two millennia ago, we may

${ }^{29}$ For a recent discussion, with earlier bibliography, see, for example, Brito (2016). 
acknowledge that some of the abuse and despair endured by the captive women on the stage reflects, with painful accuracy, a reality, though not necessarily a historical reality. ${ }^{30}$ Rather, it depicts consistent elements of women suffering during war times. Such elements we could rediscover as we read about the ordeal of young women captured in the current wars in the Middle East, or in Nigeria by Boko Haram in 2014. Thus, in a way, we may let ourselves feel deeply for the fictional world, because we know it mirrors well the reality that surrounds us. Sometimes, books and movies specifically underscore the similarities. For example, the recent Oscar nominated movie Lion (2016), directed by Garth Davies, takes us through the misadventures of a five-year Indian boy, who is separated from his family by accident; after being adopted in Australia. He decides to search for his biological mother and siblings after 25 years. The plot is based on a true story, but, something else seems important for my argument: at the end of the movie we read that 11 million kids live on the streets India, many of them going missing in a similar way. This kind of reminder enriches our interaction with fiction, because we may feel that it captures reality in a profound way. We weep not only for Saroo, the little hero of the movie, but for many other anonymous lost kids, whose stories we cannot hear. But the net of connections may not stop here, spinning more possible webs: I may remember personal experiences pertaining to abandoned children (and several come to mind, having grown up in Socialist Romania), readings on the subject (particularly Dickens' novels, which I used to love as a child), longforgotten personal fears (of being lost, far away from my parents) and some unspeakable anxieties (as a parent of how it would be like to look for a child missing). Therefore, fiction relates to our realities in myriad ways, often gaining emblematic value for our minds. And yet, could this symbolic importance that we may assign to fiction become problematic? Yes, and several have noticed, an imbalance that can occur when we invest too much emotion and thought in fictional worlds and too little in

\footnotetext{
${ }^{30}$ An interesting new collection of essays, edited by Fabre-Serris and Keith (2015), for example, explores some connections between the literary descriptions of women in war zones in Greco-Roman antiquity and historical realities.
} 
the socio-historical reality in which we live. ${ }^{31}$ One complaint can relate directly to the qualities that we have earlier attributed to successful literary creations. Because they consist of coherent and compelling narratives, they can draw us in with more emotional power than corresponding facts. But is this a good outcome? If we cry for fictional lost children because they remind us of the unfair world in which we live, and yet do nothing to save or help many abandoned or orphaned real children, it seems that we waste emotional capital.

In his comparison between dramatic poetry and history cited earlier, Aristotle notes that the former should treat events that could (always) happen, and thus the names attached to characters are only a formality, while the latter describes what did happen, as, for instance, the kind of things the historical Alcibiades did or experienced. Ironically, pseudo-Andocides discusses the outrageous behavior of Alcibiades giving several examples:

Despite his opinion about Melians (that they should be reduced to slavery) he begot a son with a Melian woman, bought from the captives. This birth was "even more illegal than that of Aegisthus" since he is born of bitter enemies. (4. 22).

Already Alcibiades' son is likened to the notorious tragic character, Aegisthus, the offspring of the incestuous relationship between Thyestes and Pelopia, who would later in the myth murder Agamemnon. The writer continues to lament that the Athenians do not seem to care about any of the atrocities that the historical Alcibiades commits, although they lament similar calamities when they see them in tragedies:

At 4.23 "Even more he had a child with the woman he turned into a slave from free, whose father and relatives he slaughtered and whose city he ruined, so that he might make his son the worst enemy of himself and of his city; he has been forced by necessity to hate them. But you, although when you watch such things in tragedies, you deem them

${ }^{31}$ I have briefly commented on this in my 2009 article, p. 130-132. 
horrible, when you see them occurring in the city, you do not worry; but you do not know whether the former have truly happened in this way or were invented (peplastai) by poets, though knowing well that the latter have happened so illegally, yet you accept them light-heartedly." 32

According to Andocides, then, the real life of Alcibiades could well be the subject of an episode of epic or a tragedy, but it leaves the observers cold and inactive. Later on, long after ancient Greece, other artists and scholars were similarly concerned with the ability of theater to drain our emotions and sometimes to desensitize us from real suffering. ${ }^{33}$ If this happens, could we find a way to correct our distorted sensitivity? In this paper, I have tried to examine why we may find the reality surrounding us duller than fiction sometimes and why, consequently, we may feel more deeply for invented stories than for real ones. The impression of proximity to literary characters, a good grip on the narrative of their lives, and the symbolic broader importance we assign to them are all explaining factors. We could further explore how to use all these elements for understanding real events. We often remain reluctant to act even when we could do something to prevent injustice and to alleviate suffering. A reason may be that we are under the constant bombardment of news describing natural and man-made catastrophes. Under the circumstances, we may find the stories confusing and may have trouble deciding when and where to intervene. Designing new ways to present

\footnotetext{
${ }^{32}$ As Edwards 1995, 203 notes in his commentary, the role of Alcibiades in the Melian massacre is exaggerated here, as he was certainly not the only one responsible for the treatment of Melos in 416/415. Thucydides does not mention Alcibiades at all in his account of the Melian dialogue (5.81-116). For Alcibiades' role, see, e.g., Plut. Alc. 16.5. ${ }^{33} \mathrm{~A}$ famous example is Brecht who did not want the spectators to invest emotionally in the theater and, afterwards, return to the world free from social and political thoughts; for a stimulating analysis of how theater and society have interacted historically, and might interact in the future, see Boal (2000).
} 
reality from a more literary than journalistic perspective could perhaps elicit better social responses from us - but that is a topic for another paper.

\section{References}

BOAL, A. Theatre of the Oppressed. New English translation Emily Fryer. Padstow: TJ International, 2000.

BRITO, H. In Praise of Aristotle's Poetics. In: HAGBERG, G. L. (Ed.). Fictional Characters: The Research for Ethical Content in Literature, Oxford: Oxford University Press. 2016. p. 305-324.

BUTLER, J. Frames of War. When is Life Grievable? London: Verso Books, 2009.

CAIRNS, D. Look Both Ways: Studying Emotions in Ancient Greek. Critical Quarterly 50, p. 43-62.

CAIRNS, D. and NELIS, D. Introduction. In: CAIRNS, D. and NELIS, D. (Eds.) Emotions in the Classical World. Stuttgart: Franz Verlag. 2017. p. 7-30.

CHANIOTIS, A. Introduction. In: CHANIOTIS, A. (Ed.). Unveiling Emotions: Sources and Methods for the Study of Emotions in the Greek World. Stuttgart: Franz Verlag. 2012. p. 11-36.

DILLARD, A. For the Time Being. New York: Alfred A. Knopf, 1999.

EDWARDS, M. The Greek Orators IV. Andocides. Edited and Translated. Warminster: Aris \& Phillips, 1995.

FABRE-SERIS, J. and KEITH, A. Women and War in Antiquity. Baltimore: Johns Hopkins University Press, 2015.

FULKERSON, L. Emotional Appeals in the Mytilenian Debate, Iowa, Syllecta Classica, v. 19, p. 115-154, 2008.

GENETTE, G. Narrative Discourse Revisited. Ithaca, NY: Cornell University Press. (First published Nouveau discours du récit, Paris, 1983), 1988.

JOHNSON, J. F. and CLAPP, D. C. Athenian Tragedy: An Education in Pity. In: STERNBERG, R. (Ed.). Pity and Power in Ancient Athens. Cambridge: Cambridge University Press. 2005. p. 123-164. 
KONSTAN, D. Pity Transformed. London: Duckworth. 2001.

KONSTAN, D. The Emotions of the Ancient Greeks: Studies in Aristotle and Classical Literature. Toronto: University of Toronto Press. 2006.

KONSTAN, D. Affect and Emotion in Greek Literature. In Oxford Handbooks Online. October 2015. <http://www.oxfordhandbooks. com/view/10.1093/oxfordhb/9780199935390.001.0001/oxfordhb9780199935390-e-41>.

KRZNARIC, R. Empathy. Why It Matters, and How to Get It. New York: Perigee. 2015.

LATEINER, D. The Pitiers and the Pitied in Herodotus and Thucydides. In: STERNBERG, R. (Ed.). Pity and Power in Ancient Athens. Cambridge: Cambridge University Press. 2005. p. 67-97.

LATTIMORE, R. The Trojan Women. Chicago: Chicago University Press. 1958.

LUSCHNIG, C. Medea in Corinth; Political Aspects of Euripides' Medea, Digressus, v. 1, p. 8-28, 2001.

MUNTEANU, D. L. Qualis tandem misericordia in rebus fictis? Aesthetic and Ordinary Emotions, Helios, v. 36.2, p. 117-147, 2009.

MUNTEANU, D. L. Tragic Pathos. Pity and Fear in Greek Philosophy and Tragedy. Cambridge: Cambridge University Press, 2012.

NÜNLIST, R. The Ancient Critic at Work: Terms and Concepts of Literary Criticism in Greek Scholia. Cambridge: Cambridge University Press, 2009.

PRICE, J. Thucydides and the Internal War. Cambridge: Cambridge University Press, 2001.

PRINZ, J. Against Empathy, The Southern Journal of Philosophy, v. 49, p. 214-233, 2011.

RABINOWITZ, N. Anxiety Veiled: Euripides and the Traffic of Women. Ithaca: Cornell University Press, 1993.

REYNOLDS, D. Mightier than the Sword: Uncle Tom's Cabin and the Battle for America. New York: Norton, 2012. 
SAPOLSKY, R. Behave. The Biology of Humans at Our Best and Worst. New York: Penguin Press, 2017.

SLOVIC, S. and SLOVIC, P. Numbers and Nerves: Toward and Affective Apprehension of Environmental Risk. Whole Terrain, v. 13, p. 14-18, 2004.

SLOVIC,P."Psychic Numbing and Genocide," < http://www.apa.org/ science/about/psa/2007/11/slovic.aspx>, 2007.

TZANETOU, A. City of Suppliants. Tragedy and the Athenian Empire. Austin: University of Texas Press, 2012.

USHER, S. Isocrates Panegyricus and To Nicocles. Warminster: Aris and Phillips, 1990.

WOHL, V. Love among the Ruins. The Erotics of Democracy in Classical Athens. Princeton: Princeton University Press, 2002.

Recebido em 20 de outubro de 2017. Aprovado em 27 de novembro de 2017. 